\title{
Deployed Sustainable Strategies to Realize Benefits from Implementation of Energy Management Systems Across Company's Multi Functioning Organizations
}

\author{
Hashim K.M. ${ }^{1}$, Hassim Mimi H..$^{*}$, Ng D.K.S. ${ }^{2}$ and Ngadi N. ${ }^{1}$ \\ ${ }^{I}$ School of Chemical and Energy Engineering / Centre of Hydrogen Energy, University Teknologi Malaysia, 81310 UTM \\ Johor Bahru, Malaysia \\ ${ }^{2}$ School of Engineering and Physical Sciences, Heriot-Watt University, No. 1, Jalan Venna P5/2, Precinct 5, 62200 \\ Putrajaya Malaysia
}

\begin{abstract}
Energy efficiency and conservation become an integral part of the business culture, and it simply means using less energy to perform the same tasks. Due to increasing internal demand on energy in many parts of the world, societal expectations for comprehensive approaches on energy efficiency have been forced into focus. As world energy demand soars, it is known that the manufacturing, power generation and transportation sectors are the main consumers to the intensive utilization of energy resources. The demand from the growing population has overwhelmed the current capacity. It is inevitable; therefore, many oil companies are now participating in on-going efforts to conserve energy, and do so in a sustainable manner by means of implementing energy management systems (EnMS) in accordance to internationally recognized standards. However, its progress has just been seen, and unfortunately, most of the oil companies are far away from matured management to excel in energy performance. Most of the oil companies consider EnMS as ambition and certificate on the wall rather than a driving vehicle to become a reference company. In fact, cost reduction is the main focus rather than to explore other hidden benefits of EnMS. More seriously, lack of dedicated measures and right strategies to push for the successful implementation. This paper discusses proven strategies that drive for full realization of EnMS benefits.
\end{abstract}

Keywords: energy engagement strategies; energy improvement program; energy improvement measures; energy management systems

\section{INTRODUCTION}

Focus on energy performance improvement has become one of the top global discussion subjects due to the facts of hiked in fossil fuel price, changed in living standards, increased in Green House Gas (GHG) awareness as well as fair business practices in related to subsidies and environment regulations (Cottier \& Delimiters, 2011). Systematic energy resources management will sustain the glory of oil companies and oil producing countries, and keep oil and gas sectors moving (Worell et al., 2006). Past history and future forecasts illustrate the rapid increase in energy demand globally. Key contributors to the intensive utilization of natural resources are coming from industrial sectors to produce consumable products. This, again, is an outcome of growing population and improving living conditions (SEEP, 2018).

Increase in energy performance focus has pushed societal expectations on oil companies to thoroughly explore ways to be more efficient. Legislative have imposed stringent requirements on environmental impact, equipment specifications, and other social obligations. In current industrial practice, an energy management systems (EnMS) is becoming one of typical initiatives that have been evolving 
since the late 1990s. According to the International Petroleum Industry Environmental Conservation Association (IPIECA), EnMS is a preferred management program to help oil companies excel in its energy utilization (IPIECA, 2013a). The first revision of EnMS was released by International Organization for Standardization (ISO) in June 2011 and was revised in 2018. EnMS engages oil companies to follow a systematic approach to manage energy resources, by means of energy efficiency applications, energy supply security, energy use and consumption reviews, performance measures, and continuous improvement efforts (ISO 50001, 2018).

Oil companies have an option to adopt new challenging realities, vibrant business models, or continue leveraging innovative technologies. Despite the increase in energy demand and societal expectations for effectiveness in EnMS implementation, it appears that EnMS is just a certificate on the wall for many oil companies (DNV.GL, 2016). In a survey conducted in April 2015 by DNV GL - Business Assurance customer on 1557 professionals from the primary, secondary and tertiary sectors of global companies on approach toward EnMS. The survey showed that $57 \%$ of the companies had an established EnMS or any similar program in place (DNV.GL, 2016). But progress had just started, and the concerned companies had not realized the full benefits of EnMS, as energy efficiency concepts had not been effectively implemented.

According to Equinor (2016), most companies believe EnMS as a slogan, rather than a condition applying to companies in running their businesses. Indeed, the main focus is to reduce cost rather than to drive for excellence in energy performance. The priority is always on financial impact rather than effort, to improve the use of energy resources (Dipaola, 2017). In contrast, firm commitments from various levels within a company' entities, establishing the right strategies, planning, executing agreed action items, and monitoring and revising strategies as necessary have yet to be embraced in a larger scope (Luca, 2018).

The full implementation of EnMS can be a major contributor to address those challenges (IPIECA, 2013b). Again, another survey was conducted by the Metrus Group, Inc. (Kaplan \& Norton, 2001) on randomly selected 122 multinational companies, to understand the relationship between energy performance to visions and strategies. Outcomes from the survey indicated that a successful company with a clear vision and strategy planning tends to benefit the most. A comprehensive EnMS requires a strong vision statement and dedicated execution strategies, followed by actual field implementation.

It is noted that having a systematic deployment strategy is one of the crucial initial steps to impel for sustainable EnMS implementation. Successful implementation of EnMS is a challenging milestone that requires the highest level of commitments from respective personnel within the company. For example, there are two identified initiatives to push for successful energy efficiency of the companies under Gulf Cooperation Council (GCC). Such initiatives are adopting and implementing a systematic EnMS.

As per Arab Forum (2013) most of companies in Arab region are encouraged to adopt energy efficiency milestones introduced by League of Arab States and implement a right energy management practices. However, it has yet to be successful to change the trends.

Surveys conducted on 22 members of the Arab League in 2013 had identified several challenges in area of concerns in achieving EnMS vision. These challenges were captured and listed in Table 1.

Table 1. Challenges to fulfil the EnMS vision (Arab Forum, 2013)

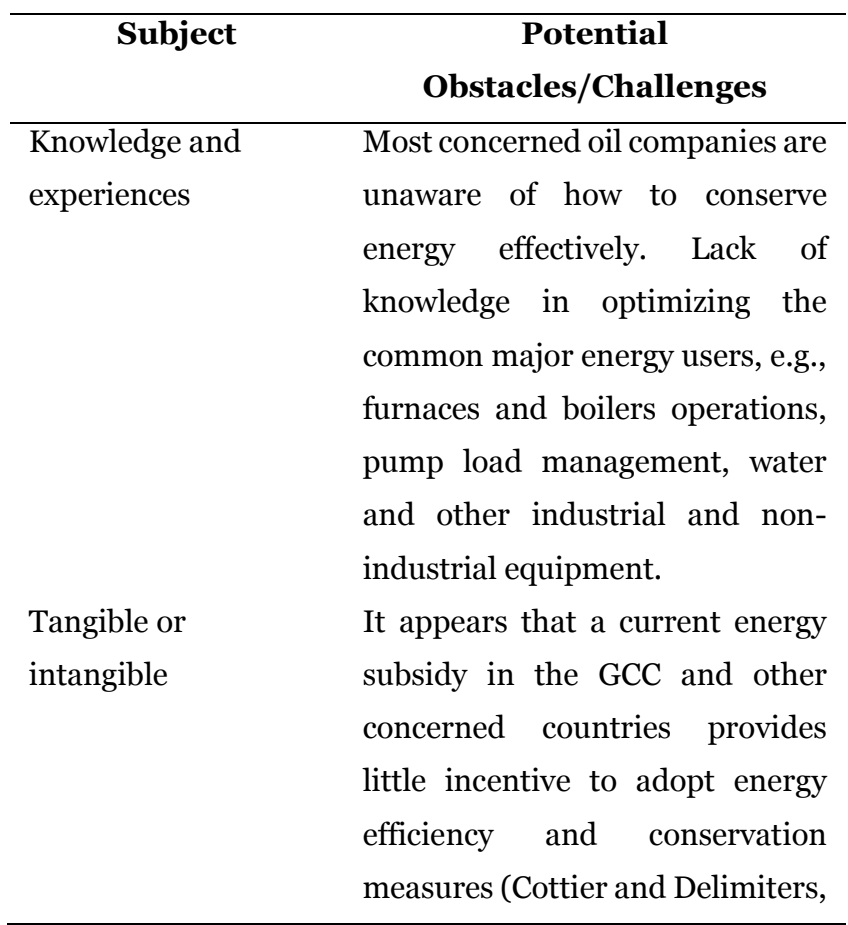




\begin{tabular}{ll}
\hline 2011). Similarly, due to low \\
energy prices, savings from \\
energy improvement efforts will \\
not be significant enough to be \\
justified under capital \\
expenditure (CAPEX) for profit \\
improvement (PI) category. \\
Oil companies facilities are \\
scattered across large areas, \\
making it difficult to coordinate \\
regional energy efficiency and \\
structure of the \\
region \\
conservation programs. \\
Energy efficiency has not been in \\
the top agenda of oil companies. \\
Many of them have yet to identify \\
energy as a significant operating \\
expenditure (OPEX).
\end{tabular}

Maximizing benefits from the desired outcomes of EnMS is a challenge that requires the highest level of planning, commitments, and a strong push by top management (Hashim et al., 2018a). Many hidden benefits and potential losses can be discovered by fully subscribing the right reference for EnMS. The main content of the proposed strategies includes simplified EnMS steps and a proven deployment starter kit that can drastically improve the implementation pace of EnMS.

The proposed strategy can induce rapid deployment and implementation of an EnMS at any concerned oil company. The strategies are driven by needs of the oil companies in fully deploying the EnMS, in which the main objectives are to optimize energy usages, reduce GHG footprint and OPEX, and remain competitive in the global arena (Galisky et al., 2005). Major phases related to the implementation strategies will be discussed in the next sections. Several examples, case studies, and best practices will be presented to prove the nature of EnMS applications, and the progress made to mitigate any potential obstacle.

\section{MATERIALS AND METHOD}

The proposed EnMS implementation strategies shall drive to meet full requirements of the recognized international standard of Energy Management Systems (ISO 50001.2018), and other specific requirements, e.g., GHG and flaring reduction as mandated by concerned oil companies (Galisky et al., 2005). According to IPIECA (2013a), ISO 50001 is very popular amongst oil companies as it provides the essential framework and guidelines for establishing a systematic energy improvement platform. Subsequently, it should be simple to expedite for sustainable implementation of EnMS within an acceptable time frame.

Other alternative energy management programs are also available such as British Standard (BS EN 16001, 2018) and Superior Energy Performance (ANSI/MSE 50028-1, 2019). These programs are almost similar to ISO 5000:2018.

A clear define objective and engagement from top management are the key success of the study. It starts with collecting information and reviewing applicable references, e.g., industry best-practices, case studies, books, journals, and related articles. Subsequently, any applicable information will be used to determine the most effective approaches and initiatives to enhance EnMS implementation. The next stage is to conduct a comprehensive analysis of successful best practices and strategies applied by several leading oil companies. Finally, a case study for the successful implementation of the said strategies at one of oil companies located in GCC will be included in the paper.

Figure 1 illustrates the major steps to be taken prior to accomplish the study objective.

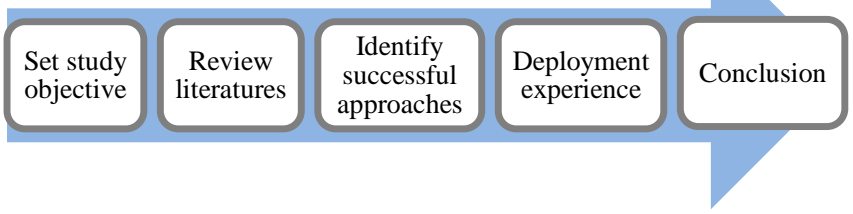

Figure 1. Study steps

\section{RESULT AND DISCUSSION}

The following sub-titles will discuss the detailed mechanisms, to define suitable strategies to enhance EnMS implementation at the concerned oil companies. It follows with a case study at one of the leading oil companies.

\section{A. Define Challenges in Deploying EnMS}

In general, there are many common factors that affect the slow progress of EnMS implementation among oil companies (Altuwayrish, 2016). According to the surveys conducted on 30 oil companies located in Gulf Cooperation Council (GCC), 
several major challenges in implementing EnMS were captured and summarized. Subsequently, identified realistic mitigations were collected to address those challenges and will be discussed in detail in the next section. The findings based on the summarized challenges that prevent oil companies from achieving the full benefits of deploying and implementing the EnMS are listed in the first column of Table 2. References were also made to previous literatures on similar issues in other Middle East companies (Arab Focus, 2013) as well as globally (Petroleum Media, 2015).

Table 2. List of typical EnMS implementation challenges and proposed strategies

\begin{tabular}{|c|c|}
\hline Cha & $\begin{array}{c}\text { Identified implementation } \\
\text { strategy }\end{array}$ \\
\hline $\begin{array}{l}\text { Set clear corporate } \\
\text { direction }\end{array}$ & $\begin{array}{l}\text { - Identify tangible and intangible } \\
\text { benefits by implementing } \\
\text { EnMS } \\
\text { - Indicate clear link to respective } \\
\text { business goals } \\
\text { - Fulfil energy policy } \\
\text { expectations } \\
\text { - Gather commitment from } \\
\text { management through regular } \\
\text { updates }\end{array}$ \\
\hline $\begin{array}{l}\text { Gain commitments } \\
\text { from: }\end{array}$ & $\begin{array}{l}\text { - Introduce e-learning courses to } \\
\text { senior and middle management }\end{array}$ \\
\hline $\begin{array}{l}\text { a. Top management. } \\
\text { b. Energy coordinator } \\
\text { c. All critical } \\
\text { positions }\end{array}$ & 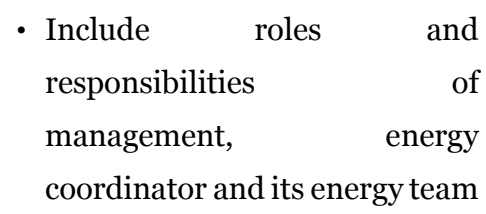 \\
\hline $\begin{array}{l}\text { d. Employees and } \\
\text { contractors }\end{array}$ & $\begin{array}{l}\text { in EnMS reference document } \\
\text { - Provide relevant awareness } \\
\text { events such as e-learning } \\
\text { courses, workshops, technical } \\
\text { exchanges meetings, forums } \\
\text { and conferences }\end{array}$ \\
\hline $\begin{array}{l}\text { Solve conflicting } \\
\text { priority }\end{array}$ & $\begin{array}{l}\text { - Appointment letters for energy } \\
\text { related personal } \\
\text { - Include in individual } \\
\text { performance goal for each } \\
\text { member of energy team }\end{array}$ \\
\hline Enhance competency & $\begin{array}{l}\text { - Develop list of recommended } \\
\text { courses }\end{array}$ \\
\hline
\end{tabular}

- Include detailed qualification of critical EnMS positions in the framework

Energy data analysis, monitoring,

corrective and

preventive

High cost of

implementing EnMS
- Specify energy performance indicators (EnPIs)

- Establish data collection mechanism

- Simplify operating manuals Embed into existing companywide management programs

\section{Obtain full \\ Implementation}

Increase pressure

from society, e.g., new product and legal requirements
- Gain momentum with other matured programs implemented by companies

- Introduce self-evaluation assessment

- Adopt the right EnMS reputable standards, which;

- Proven to lead for energy performance improvement

- Simplicity to users

- Consistency with other management programs such as environmental management systems (EMS), safety management systems (SMS), total productive maintenance (TPM) and other matured programs

- Establish lessons learned and best practices

\section{B. Deploy Strategies to Gain Full Benefits of EnMS}

The surveys outcomes from Section A identify that one of the critical strategies to gain full realization of EnMS is to establish a clear link to one of more company' business goals. Benefits of deploying EnMS and how it can contribute to achieve related business goals should be explored and shared to respective entities. Business goals may vary among oil companies. The most common ones are to improve productivity by lowering operating costs and reducing environmental impacts (IPIECA, 2013a). Several other benefits of adopting systematic EnMS follow (IPIECA, 2013a): 
- Achieving applicable business goals through wellstructured EnMS.

- Gaining globally recognized international standards for utilizing and managing energy resources.

- Specifying accountabilities and responsibilities in managing energy resources.

- Identifying problems and opportunities for improvement proactively.

- Standardizing and enhancing major energy-related work processes across the company functions.

- Enhancing asset integrity and reliability techniques and processes.

- Mandating decision-making processes from system design.

- Assisting in compliance with current and future voluntary and/or mandatory energy efficiency targets.

- Improving corporate image and credibility among customers, clients and stakeholders.

- Increasing energy awareness among staff members and contractors.

A successful EnMS implementation requires systematic strategies. Depending on companies' specific initiatives, the proposed mitigation strategies have been identified based on respondents' feedback and proven best practices captured from the literatures. Identified implementation strategies are listed in column 2 of Table 2 and summarized as per following;

- Engage in top management involvement.

- Subscribe to reputable and latest EnMS standards.

- Focus on energy savings.

- Embed EnMS into existing and matured management programs.

- Introduce a comprehensive framework template.

- Provide energy improvement guidelines template.

- Define performance monitoring campaigns.

Detailed on each of implementation strategy will be described in the following sub-title 1 to Section 7.

\section{Engage top management involvement}

Successful implementation of EnMS is a challenging milestone that requires the highest level of commitments from the top management of any concerned oil company. Energy should be considered as one of significant operating cost parameters and the one that should be always important to management and concerned stakeholders (Turner, 2001). Therefore, these expectations should be part of a viewpoint to the EnMS. According to the IPIECA (2013a), the EnMS shall consist of customized steps to address each applicable business goals of concerned companies.

To be able to win the management buy-in, the concerned management should be provided with a clear linking of all related steps to defined business goals, e.g., HSE, cost efficiency, reliability and profitability. With a clear picture, it can promote the importance of EnMS to the highest level at par with other matured programs, e.g., SMS, EMS, TPM, and several other programs. Figure 2 illustrates the links between expectations, steps of EnMS, and each business goal.

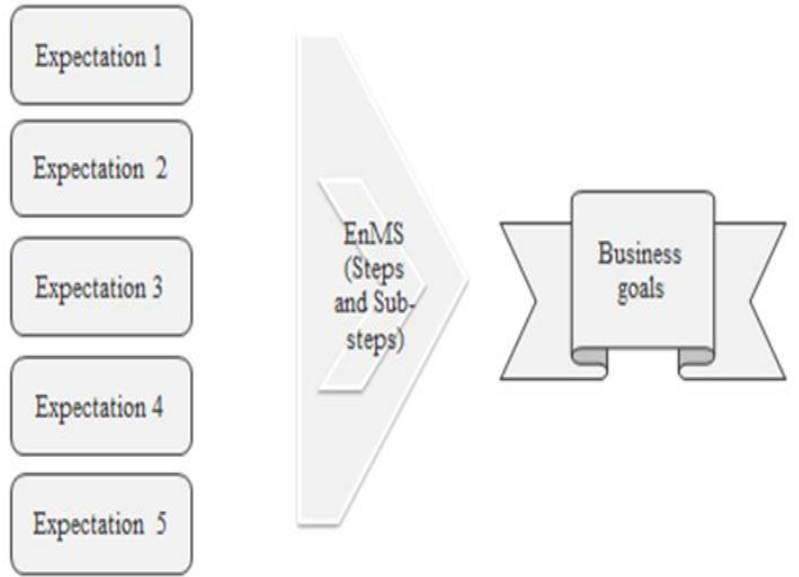

Figure 2. Linking between expectations, EnMS' steps and applicable business goals

The management of concerned oil companies should be convinced about tangible and intangible advantages for implementing EnMS. They shall be informed that the main benefit of the EnMS is to serve as an effective and sustainable process that can induce productivity. In addition, the EnMS pushes in enhancing environmental performance by reducing GHG emissions and natural resources intakes. A number of benefits can be realized with the embracing solid EnMS, which focuses on minimizing energy consumption in each process unit, area, or activity.

The firmed commitment from top management is the key success of the program. Many measures that can trigger management focus. Such measures are summarized from the received feedback from surveys, as well as by referring to lessons learned from proven sources. The main one is to link 
to most of the business goals. In reality, focusing on energy conservation and efficiency efforts can tremendously reduce GHG footprint, minimize the release of hazardous emissions, pollution, and many other HSE impacts. In addition, EnMS will drive for improvement in energy utilization, reliability of services or products as well as cost and profitability (Hashim et al., 2018a).

\section{Subscribe to reputable and latest standards}

The United Nations Industrial Development Organization (UNIDO) has concluded that industries around the world need to implement an effective response to climate change (UNIDO, 2010). In 2007, UNIDO requested ISO to develop an international energy management standard as preferred reference documents. Subsequently, a committee was established in 2008 to draft the dedicated energy management standards. EnMS (ISO 50001:2011) was officially announced and published for global adoption in 2011 (ISO 50001, 2011). Since then, ISO 50001:2011 has become a major reference and has replaced a number of energy management related standards such as BS EN 16001 (British Standard for Energy Management), Superior Energy Performance (SEP) from American National Standards Institute (ANSI), Energy Star from USA' Environment Protection Agency (EPA) and other related energy efficiency practices (IPIECA, 2013a). In 2018, new revision of ISO 50001(ISO 50001, 2018) was released after incorporating feedbacks from implementers around the globe (ISO 50001, 2018).

Subscribe to reputable and latest international standards of ISO 5000:2018 help to strengthen EnMS governance. The management should be informed that gaining an ISO 50001 certification is evidence to demonstrate company commitment to fulfil Conference of the parties (COP) 21 (Worland, 2015) in reducing GHG generation and other environmental impacts as expected by stakeholders. Tapping to recent well-proven practices, such as the latest international standards of ISO 5000:2018 is a well-proven strategy measure to excel in energy performance.

EnMS' steps are accordance to Deming' Plan-Do-Check-Act (PDCA) cycle (Pyzdek \& Keller, 2013). A brief description of EnMS related PDCA is listed in Table 3.
Table 3. Description on main element of EnMS (IPIECA, 2013a)

\begin{tabular}{ll}
\hline Main step & \multicolumn{1}{c}{ Brief description } \\
\hline Plan & Establish policy, assign function and \\
& responsibilities, set objectives and targets, \\
& create a monitoring campaign, and define \\
& energy plans \\
& Establish policy, assign function and \\
Do & responsibilities, set objectives and targets, \\
& create a monitoring campaign, and define \\
& energy plans \\
& Raise awareness, improve competency, and \\
Check & identify energy savings opportunities, as \\
& well as efficiently operate identified \\
& significant energy uses (SEUs) \\
& Conduct management review, recognize \\
act & enhance energy performance
\end{tabular}

Simplified EnMS steps and its relationship between each EnMS element as per PDCA cycle is concluded and illustrated in Figure 3.

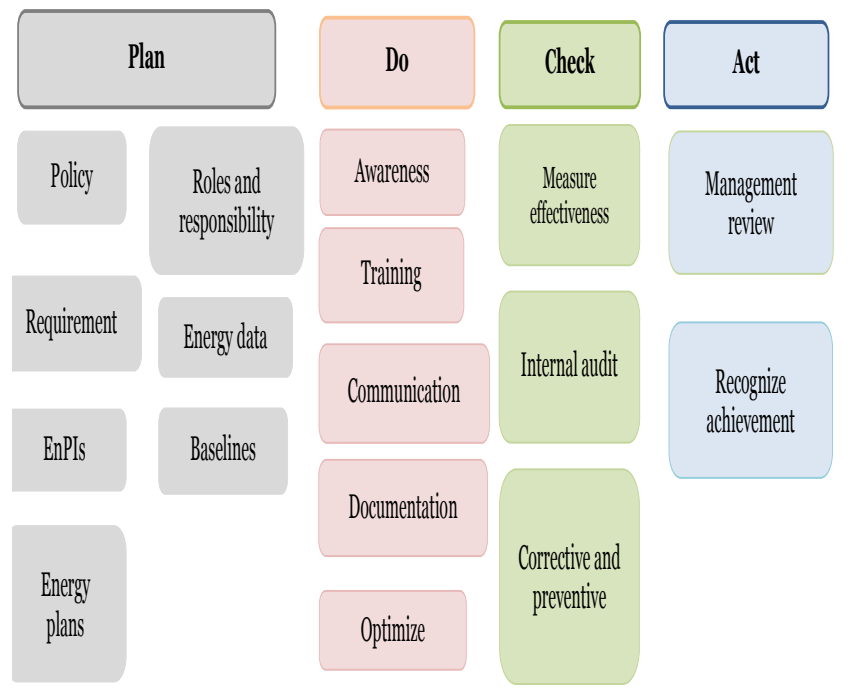

Figure 3. Simplified EnMS steps ((Hashim et al., 2018a)

\section{Focus on energy savings}

Implementing the EnMS requires a solid effort and commitment from the concerned oil companies (IPIECA. 2013a). Therefore, the review shall be conducted to ensure the concerned companies can gain significant benefits by implementing the EnMS. The first action to be conducted prior to engaging concerned oil companies is to check the 
applicability to EnMS as a pre-requisite. It is very important to ensure that EnMS will benefit them, and will eliminate unnecessary allocation of resources. In addition, defining the applicability of each company is important to ensure the EnMS is not overwhelmed. It will provide encouraging messages to the concerned entities for their contribution in achieving the specific goals.

Applicability to the EnMS requirements can be determined based on the defined requirement, such as consumption limits, as indicated by Table 4 . Several countries such as Malaysia, Australia, and Singapore have issued a mandatory requirement on EnMS participation for certain industries, including refineries, petrochemicals, and other production facilities.

Upon meeting the threshold limit as defined by respective companies, the development of energy policy and other steps and sub-steps as required by its adopted EnMS guidelines will follow. Subsequently, any applicable company shall proceed to establish EnMS in accordance to the subscribed standards.

Table 4. Threshold limit for implementation of EnMS

\begin{tabular}{ll}
\hline \multicolumn{1}{c}{ Country } & \multicolumn{1}{c}{$\begin{array}{c}\text { Minimum annual energy } \\
\text { consumption, GWhr }\end{array}$} \\
\hline Australia & 139 (Australia Government, 2013) \\
Singapore & 15 (National Environment Agency, \\
& 2013) \\
Japan & 12 (or 30oo kiloliters of crude oil*) \\
& (Japanese Government, 2013) \\
Malaysia & 6 (EMEER, 2008) \\
ISO 50001:2018 & No limit**(ISO 50001, 2018) \\
\hline Note: $\quad{ }^{*}$ HHV Crude oil (GJ/Kiloliter): 30 \\
\multicolumn{2}{c}{ *Applies to companies that use energy and } \\
responsible for its cost and maintenance.
\end{tabular}

\section{Embed EnMS into matured management programs}

The surveys in section A indicate that prior to a push for EnMS implementation in oil companies, strong efforts from all employees and respective contractors are required. In most oil companies, EnMS is not in the priority list or even mentioned in business goals, particularly in national oil companies. To embed EnMS as part of an aggressive management initiatives model is a preferred strategy, to drive for drastic improvement progress. The model depends on specific company characteristics, such as political, sociocultural, economic, technological, environmental, and legal application (Mullins, 2005).

As an outcome from the surveys (Section A), it appears that EnMS is a required driving vehicle to ease supports from concerned company' entities. In this case, EnMS can be embedded as part of matured management initiatives models. A strong push through common management platforms is required, e.g., total quality management (TQM), operational excellence model (OEM), reliability-centred management (RCM), TPM or lean six sigma (LSS). This is a smart way to impel energy efficiency application within the company.

One of the leading oil companies has successfully improved the implementation of EnMS under the umbrella of OEM (Hashim et al., 2018a). It is a proven methodology that induces overall success to this company by saving significant amounts of energy and reduction in tons of GHG. Subsequently, the company realizes the other intangible benefits that enhance their performance, such as gaining competitive advantage in improving their business performance and becoming a reference company. Adopting the OEM driving platform will benefit the concerned oil companies by means of the following:

- Standardization and enhancement of major work processes across the company functions.

- Reduce time spend during development, implementation, performance monitoring and governing the EnMS.

- Capture and dissemination of tacit knowledge retained by a few subject matter experts.

- Clarification of accountabilities and responsibilities to function within any concerned company.

- Enhancement of asset integrity and reliability techniques and processes.

- Engage full attention to all required expectations, processes, and business goals.

- Optimize resources through consolidating compliance assessment on other matured programs.

\section{Introduce a comprehensive framework template}

The framework template includes all relevant references as well as examples and is tested for practicality. It has to be simple and provide a clear description that can attract any 
applicable oil company to deploy EnMS effectively. EnMS implementation requires a strong commitment from the entire company. With allocation of adequate resources such as man-power, operating and investment cost to drive for improvement in energy performance.

The purpose of comprehensive framework template is to assist concerned oil companies to ease the time and effort to deploy and implement an EnMS. Main contents of the proposed framework are simplified EnMS steps and substeps in reference to ISO 50001:2018. The framework is embedded with proven deployment tips that can drastically improve the implementation pace of EnMS. Subsequently, deploying a customized EnMS will drive the concerned companies towards integrating the relevant steps or substeps into its existing programs. Therefore, it will benefit each company in resource allocation, shortcutting the introduction process and focuses on criticality.

With the introduction of a comprehensive EnMS framework template which includes checklists, typical EnPIs, plans and many other critical steps and sub-steps, it induces EnMS as one of excellent programs to be expedited. The established EnMS shall consist of necessary clauses to address identified business goals and evident its criticality. The EnMS framework template provides a structured approach to achieve and sustain a leading performance in their specific areas, while striving on effectiveness and profitability. Following a framework template is something that companies must attempt to adopt and to start with. The truly successful ones are those who implement a comprehensive EnMS framework template effectively.

\section{Provide energy improvement guidelines template}

Most oil and gas production facilities are technologypervasive industries. These types of industries require high capital investment with highly diverse concerns including associated business risks, HSE related impacts, stakeholders, and socio-politics of the hosting countries. The benefit of deploying new technologies and innovations shall balance the potential downside of a failure (Hashim et al., 2018b). Inclusion of energy improvement guidelines with focusing on self-help and quick fix initiatives can partially reduce the gaps, and then strengthen it to pave the way towards improving companies' profitability.
Energy savings can be realized by focusing on initiatives, e.g., operational improvement, quick fix or an initiative that requires a high CAPEX. Also having an energy improvement team (EIT) to explore energy savings opportunities. The team must exert rigorous efforts, including technical competency on energy-related subjects, securing support from management, and establish reference guidelines. Ideally, the guidelines should be established based on energy improvement know-how, best-practices, lessons learned and well-known literature from internal and external sources to ensure all significant energy efficiency concepts will not be missed.

Table 5. List of typical energy saving opportunities (Hashim et al., 2018b)

\begin{tabular}{|c|c|c|}
\hline No. & $\begin{array}{c}\text { Area of } \\
\text { opportunity }\end{array}$ & $\overline{\mathbf{A p}}$ \\
\hline 1 & $\begin{array}{l}\text { Steam loss } \\
\text { due to } \\
\text { malfunction } \\
\text { steam traps } \\
\text { and pipe leaks }\end{array}$ & $\begin{array}{l}\text { Improve steam traps reliability, } \\
\text { revisit design, and replace with } \\
\text { more efficient units and increase } \\
\text { inspection frequency. }\end{array}$ \\
\hline 2 & $\begin{array}{l}\text { High furnace } \\
\text { flue gas excess } \\
\text { oxygen levels }\end{array}$ & $\begin{array}{l}\text { Reduce excess oxygen level to the } \\
\text { optimum point and review excess } \\
\text { oxygen control scheme. }\end{array}$ \\
\hline 3 & $\begin{array}{l}\text { Burner } \\
\text { combustion } \\
\text { issues }\end{array}$ & $\begin{array}{l}\text { Check burner condition } \\
\text { frequently and make adjustment } \\
\text { as needed. }\end{array}$ \\
\hline 4 & $\begin{array}{l}\text { Steam header } \\
\text { pressure } \\
\text { control }\end{array}$ & $\begin{array}{l}\text { Reduce steam pressure to the } \\
\text { optimum limits acceptable to } \\
\text { process. Plant test may be } \\
\text { required. }\end{array}$ \\
\hline 5 & $\begin{array}{l}\text { Cooling water } \\
\text { system - high } \\
\text { water } \\
\text { circulation } \\
\text { and fans } \\
\text { control }\end{array}$ & $\begin{array}{l}\text { Reduce number of pumps in } \\
\text { operation and introduce fans } \\
\text { operating strategy. Plant test is } \\
\text { required. }\end{array}$ \\
\hline 6 & $\begin{array}{l}\text { High plant } \\
\text { water usage }\end{array}$ & $\begin{array}{l}\text { Reduce overall plant water usage, } \\
\text { cooling water improvement, } \\
\text { piping reliability and water saving } \\
\text { awareness events. }\end{array}$ \\
\hline 7 & $\begin{array}{l}\text { Poor motor } \\
\text { efficiency }\end{array}$ & $\begin{array}{l}\text { Revise maintenance procedure in } \\
\text { replacing and procure motors. }\end{array}$ \\
\hline
\end{tabular}




$\begin{array}{lll}8 & \text { High steam } & \text { Reduce deaerator working } \\ \text { deaerator } & \text { pressure to minimize steam used } \\ \text { vents } & \text { for scrubbing. Plant test is } \\ & \text { required. }\end{array}$

Examples of widely accepted energy saving initiatives are listed in Table 5. The implementation measures are preliminary, and further confirmations are required to be quantified. In fact, each identified initiative shall be evaluated promptly through the following subject items (Turner, 2001):

i. Technical evaluation to ensure each proposed initiative is technically acceptable.

ii. Operational evaluation to check for implementation practicality on each proposed initiative.

iii. Simple risk analysis such as strength, weakness, opportunity and threat.

iv. Incentives: financial, GHG reduction and carbon trading program.

v. Process safety management (PSM) review such as management of change (MOC), hazard and operability study (HAZOP) review and other specific requirements for each applicable company.

vi. Initiative execution plan.

vii. Decision making and path forward plan.

v. Method of verifying results

Ultimately, the energy improvement guidelines template should provide a brief description of typical energy improvement initiatives as per the following subjects (Hashim et al., 2018b):

- Introduction of scope and coverage of the improvement guidelines. It shall include expectations for energy coordinators, members of its energy team as well as other energy critical positions.

- Description of specific procedure based on company' know-how and external best practices, lessons learned and well-known literatures, but not limited to the following scope:

- Energy programs provide a mechanism for continuous improvement in energy performance, e.g., planning, training, communication, accountability, monitoring, reporting, feedback and recognition.

- Performance monitoring approach to track progress of energy optimization program.
- Measuring and metering are critical to ensure successful energy performance monitoring efforts.

- Heat exchanger improvement program.

- Furnaces/Fired boiler improvement program.

- Air preheaters' improvement program.

- Waste heat recovery units improvement program.

- Steam systems improvement program.

- Electrical systems improvement program.

- Flare systems improvement program.

- Vacuum systems improvement program.

- Rotating equipment improvement program.

- Miscellaneous heating/cooling systems and insulation.

- Effluent treatment plant.

\section{Define performance monitoring program}

The first task for continual improvement in energy performance is to define EnPIs. A right selection of EnPIs will enhance tracking of the overall implementation progress against defined EnMS expectations and other desired performance targets (Lindberg et al., 2015). Moreover, dedicated actions can be taken to correct them as a defined duration. EnPIs will ensure common objectives of EnMS (e.g., increase reputation, improve energy intensity, reduce cost and GHG emissions) are met (Nuaim, 2019).

The ultimate approach is to apply lagging and leading EnPIs. The lagging EnPIs are based on actual operational data that reflect the as-is situation of energy performance and are commonly applied by oil companies (IPIECA, 2013a). A basic measure of lagging EnPI is also known as Energy Intensity (EI) or Energy Utilization Index (EUI) in industry and building. EI is a measure of the energy required in generating a unit of products (Solomon, 2013). Meanwhile, EUI is a measured value of the amount of energy annually used for cooling or heating a building or facility per area of conditioned space (Turner, 2001).

Overall progress in driving for continuous improvement in the energy performance can be tracked through the leading EnPI (Hashim et al., 2019). It appears that the leading EnPI is a preferred tracking tool to monitor the progress of continuous improvement in overall energy performance, tracking performance scorecard, and reporting results of EnMS implementation (Marcus, 2011). Leading EnPI can also be applied to monitor the progress against the 
implementation objectives of EnMS in which companies are deployed (Estes, 2009).

As to summarize, the proposed leading EnPI indicators can be applied to assist concerned companies in tracking their leading performance, as per the following (Hashim et al., 2019):

- Implementation status of energy improvement initiatives.

- Energy performance trends such as energy efficiency by product, process unit and major equipment

- Status of achievement to meet the energy objectives and targets.

- Effectiveness of operational and maintenance activities to enhance energy efficiency.

- Level of awareness among the companies' management and employees.

- Level of competency of energy related personnel.

- Internal EnMS assessment performance.

- Overall implementation status of EnMS.

\section{Real Site Deployment of EnMS}

A real site application at one of the oil companies located in GCC has successfully implemented the EnMS. Referred to as NOC-X, it has initiated the EnMS at corporate level since the year 2005, even before the establishment of internationally recognized ISO 50001 for EnMS standard in mid of 2011 (ISO 50001, 2011). In 2012, over 50 applicable organizations under NOC-X were requested to embrace each element of the established EnMS guidelines. The major goals for the request include becoming more energy efficient, energy responsible, and to be able to demonstrate this responsibility to stakeholders, the government, and the public. The main reference for NOC-X' EnMS is the one published by ISO Standards (ISO 50001: 2011).

In the initial stage of EnMS implementations, delays can occur due to a lack of commitment or even rejection from respective parties. Some company organizations may not understand how to apply EnMS. These delays can be compounded by a lack of support from top management, limited resources, and geo-political structure.

Surveys were conducted to realize the full benefits of implementing EnMS. After conducting a number of surveys, reviews, and brainstorming sessions, NOC-X concluded with the following implementation recovery strategies:

- Embedded EnMS under OEM umbrella.

- Confirmed applicability of the EnMS to impel energy savings.

- Introduced a comprehensive framework template to ease deployment of EnMS for new identified organizations.

- Concluded performance monitoring program. Both lagging and leading EnMS have to be included in the monitoring program.

- Published energy improvement guidelines.

The applicability of each of the NOC-X' organizations to EnMS was determined in Table 6. As of 2017, more than 50 organizations had successfully confirmed their applicability, based on this checklist. It provided a solid justification for these organizations to deploy the EnMS prior to earning cost savings. In addition, it could sustain their financial performance by reducing operating cost, and minimizing expenses associated with environmental-related activities. Ultimately, these organizations started to link EnMS to certain business goals, particularly "efficiency" and "environment".

Table 6. Threshold limit for implementation of EnMS applied by NOC-X

\begin{tabular}{|l|l|l|l|}
\hline No. & \multicolumn{1}{|c|}{ Questionnaires } & Yes / No & Remark \\
\hline 1 & $\begin{array}{l}\text { Does your organization } \\
\text { consume electricity or fuel } \\
\text { or any other form of energy } \\
\text { above 21,ooo } \\
\text { mmBTU/year Note-1? }\end{array}$ & $\begin{array}{l}\text { Does your organization } \\
\text { involve in energy } \\
\text { (powerNote-2) generation for } \\
\text { internal or external use? }\end{array}$ & \\
\hline 2 & $\begin{array}{l}\text { Does your organization } \\
\text { involve in the production of } \\
\text { energy resources }\end{array}$ & & \\
\hline 3 & $\begin{array}{l}\text { Doese-3? your organization } \\
\text { require to establish EnMS } \\
\text { by local authority }\end{array}$ & & \\
\hline Note-4? & & \\
\hline
\end{tabular}

Definitions;

Note 1: Approximate 6 GWhr/year

Note 2: Electricity 
Note 3: Oil and gas

Note 4: Statutory requirement

Enhancement took place in 2013, as NOC-X introduced the OEM to strengthen its business portfolio, and the EnMS was concluded as one of the NOC-X' critical programs. Deployment of EnMS as part of OEM is an effective strategy to promote and mandate full EnMS implementation company-wide. Part of the implementation methodology is to customize EnMS by incorporating selected expectations from OEM. In addition, adoption of EnMS into OEM will enhance management commitment and provide clear links to NOC-X relevant business goals.

The essential EnMS deployment initiative of the framework template was introduced to the concerned organizations of NOC-X in late 2015. NOC-X has fully relied on this template as the main reference to deploy the EnMS since it was considered new to the company. The framework template is an important quick reference of EnMS to ease deployment and later to push for full implementation of EnMS by applicable organizations. The framework template includes all relevant steps, sub-steps, activities and guided approaches for a successful implementation of the EnMS. The comprehensive EnMS framework template will allow any concerned organization to quickly establish and therefore integrate EnMS into their management practices, including fine-tuning production processes and improving the energy efficiency of their systems.

In fact, the main convincing factor of successful EnMS implementation in the eyes of management is the cost savings gained. Thus, the introduced energy improvement guidelines are purposely to describe a methodology of quick energy assessment approaches. Therefore, energy improvement can be conducted faster and effectively. Quick energy assessment methodology is a step-by-step manner that includes simple data representation models and checklists for identifying and evaluating energy saving initiatives. The guidelines are intended to be a main reference to energy coordinators, energy engineers, specialists or other concerned energy practitioners responsible for efficient operation of their organizations.

To track the overall organization energy performance, lagging EnPI concept of energy consumed in gigajoule (GJ) over the final product in metric ton is used as a basis for EnPI calculation. Due to confidentially, these tracking trends will not be revealed. For example, EnPI for the Downstream facility of Purified Terephthalic Acid (PTA) is shown in Figure 4. The target line is marked on the chart to indicate its energy performance easily.

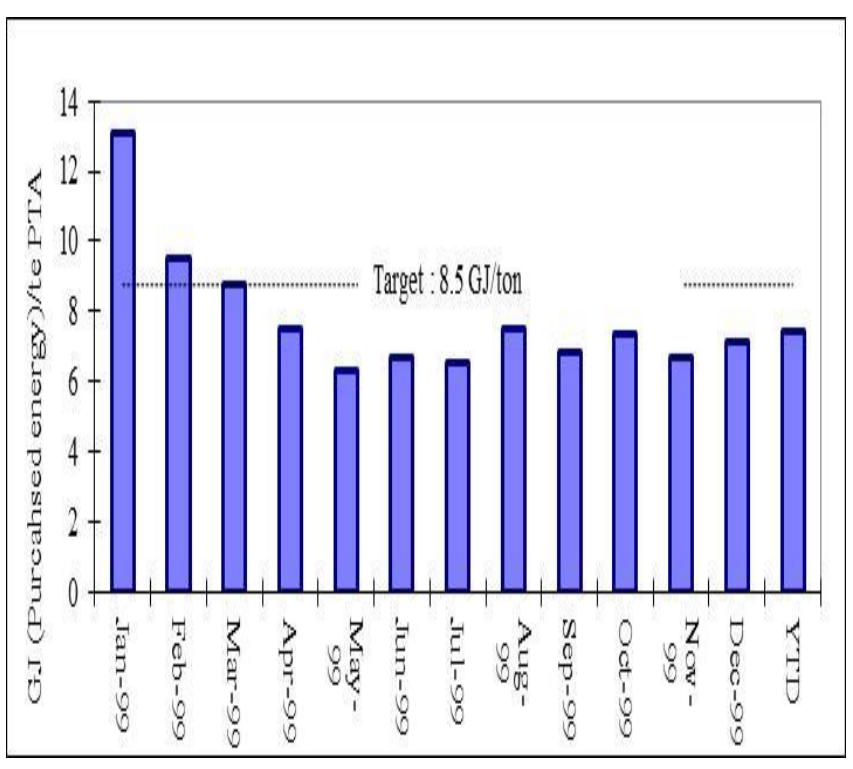

Figure 4. EnPI for one PTA manufacturing facility (Hashim, 2004)

A leading EnPI has been successfully implemented to track NOC-X organization progress towards excellence in energy performance. At defined interval, each of the concerned organization conducts a comprehensive self-assessment, based on customized questionnaires, to gauge the progress of its EnMS implementation against EnMS critical steps, e.g., Plan is to define energy plans, Do is to conduct improvements, Check is to track energy plans implementation, and EnPIs, Act is to conduct management reviews. The customized EnPI was based on an allocated weight for each of the major EnMS stages as per the Deming quality cycle of PDCA, where a certain weight to reflect the current needs of each organization was given. The maximum weight of $100 \%$ will be allocated to an organization that fully meets all agreed expectations. In this case study, the allocation for PDCA was an equal weight of $25 \%$ (Hashim et al., 2019). 


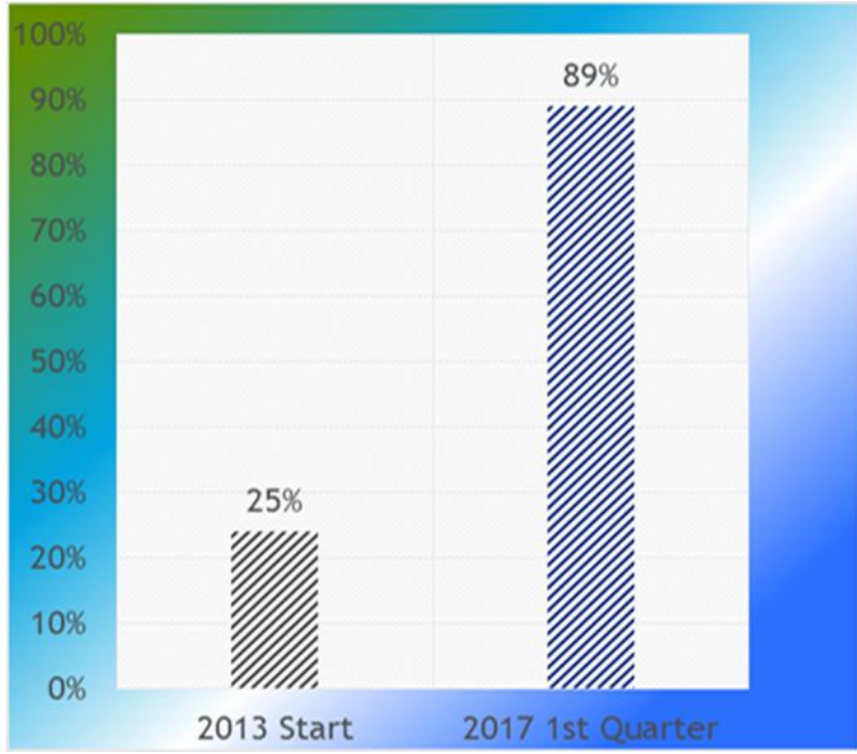

Figure 5. Company EnMS implementation progress

\section{CONCLUSION}

Main sustainable measures can be realized by full implementation of EnMS, which include reduction in OPEX from energy improvement, minimization of environment impacts through well-structured energy resources management, and enhancement of the company image in the eyes of stakeholders, by engaging international recognized EnMS.

Seven strategies can be considered to ease EnMS deployment and implementation by any concerned oil company. Such strategies, e.g., engage top management commitment, subscribe to reputable and latest standards, ensure the EnMS impels for energy savings, embed EnMS into existing and matured management programs, introduce a comprehensive framework template, provide an energy improvement guideline, and define the performance monitoring campaign.

This paper describes proven strategies that have and been successful applied by many organizations in one oil company. It is evident from the case study that the proposed strategies such as embedded EnMS as one of the OEM critical processes, applied comprehensive framework template as a deployment/ implementation starter kit, and tracking energy improvement are managed to engage strong commitments from all level of employees. The number of benefits and the opportunities for improvement will be captured during the actual deployment of EnMS. One of the major benefits is to ease the adaptation of the strategies, and ultimately drive for steady incremental improvements in energy performance. It is based on proven methodology, easily implemented and minimum resources.

\section{ACKNOWLEDGEMENT}

The authors would like to express their sincere gratitude to one anonymous national oil company for providing access to the venue and facilities during the case study.

\section{REFERENCES}

ANSI/MSE 50028-1. 2019, Superior energy performance $50001^{\mathrm{tm}}$ program - additional requirements for energy management systems, American National Standards Institute (ANSI) for Superior Energy Performance. Washington DC, USA.

Australia Government 2013, Energy savings measurement guide. how to estimate, measure, evaluate and track energy efficiency opportunities, Australia' Department of Resources, Energy and Tourism Version 2, Australia.

Arab Forum 2013, Environment and development executive report summary recommendations, Arab environment sustainable energy prospect, challenges, opportunities, Beirut, Lebanon.
Altuwayrish, B 2016, 'Site energy management systems (enms) development and implementation in Saudi Aramco', in Proceedings of the 1oth Middle East Refining and Petrochemicals Conference, 26 September 2016, Bahrain.

BS EN 16001. 2019, Energy management systems requirements with guidance for use, British Standards Institution, UK

Cottier, T. \& Delimiters P 2011, The prospects of international trade regulation from fragmentation to coherences, 1st edn, Cambridge University Press, UK.

Dipaola, A 2017, Saudis kick off $\$ 50$ billion renewable energy plan to cut oil use, bloomberg, $<$ https://www.bloomberg.com/news/articles/2017-02- 
20/saudis-kick-off-50-billion-renewable-energy-plan-tocut-oil-use $>$.

DNV.GL 2015, Saving energy today for brighter tomorrowViewPoint report, https://www.dnvgl.com/assurance/viewpoint/viewpointsurveys/energymanagement2015vp.html>.

Estes, J 2009, Smart green: how to implement sustainable business practices in any industry-and make money, 1st edn, John Wiley \& Sons, US.

EMEER 2008, Efficient management of electrical energy regulations 2008, Electrical Supply Act (P.U. (A) 444).

Equinor 2016, 'Equinor warns that the energy transition is "too slow", Near Surface Geoscience Conference, vol. 36, no. 3 , pp. 31 .

Galisky AD 2005, Energy improvement in the petroleum refining industry, Summer Study for Energy Efficiency in Industry, Associate Energy Engineers, USA.

Hashim, MK 2004, 'Water management study for BP chemicals (m) sdn bhd', MSc. thesis, Universiti Teknologi Malaysia, Johor, Malaysia.

Ng, DK \& Hassim, MH 2018, 'Advancing energy performance in oil and gas industry through systematic implementation of energy efficiency programs by applying an operational excellence model', Journal of Energy and Safety Technology, vol. 1, no. 2, pp. 51-59.

Ng, DK \& Hassim, MH 2018, 'identify energy savings opportunities from operational "self-help "and "quick fix" optimization approaches', Journal of Energy and Safety Technology, vol. 1, no. 2. pp 41-49.

Hassim Mimi, H, Hashim, KM, Ng, DKS \& Ten, JY 2019, 'Leading energy performance indicator: tracking of energy management systems in oil and gas companies', ASM Science Journal, vol. 12, pp. 1-16.

IPIECA 2013, 'Guidelines for implementing ISO 50001 energy management system in oil and gas industry', in The global oil and gas association for environment and social issues climate change, International Association of Oil and Gas Producers, London, UK.

IPIECA 2013, 'Saving energy in the oil and gas industry', in The global oil and gas association for environment and social issues climate change, International Association of Oil and Gas Producers, London, UK.

ISO 50001 2011, Energy management systems requirements with guidance for use, International Standards Organization. Switzerland.
ISO 50001 2018, Energy management systems requirements with guidance for use, International Standards Organization. Switzerland.

Japanese Government 2013, 'Cabinet decision on the bill to partially amend the act on the rational use of energy (energy conservation act), Japanese Minister of Economy, Trade and Industry Press Release, 5 March 2013.

Kaplan, R \& Norton, D 2001, The strategy-focused organization: how balance scorecard companies thrive in the new business environment, 1st edn, Harvard Business School Press, US.

Luca, C 2018, 'Regain trust by aligning with society's need', Journal of Petroleum Technology, vol. 70, no. 6, pp 14.

Lindberg, CF, Tan, S, Yan, J \& Starfelt, F 2015, 'Key performance indicators improve industrial performance', Energy Procedia, vol. 75, pp. 1785-1790.

Marcus, A 2011, 'ICT and eco-sustainability working group for McKinsey and company', in World Economic Forum, 26 January 2011, Davos, Switzerland.

Mullins, L.J 2005, Management and organizational behavior, 7 th edn, Prentice Hall, UK.

Nuaim, AS 2019, 'One year of sustainability is not enough', Journal of Petroleum Technology., pp. 10.

National Environment Agency 2013, Singapore's mandatory energy management requirement, Energy Conservation Act (ECA), Singapore.

Petroleum Media 2015, 'Implementation of petroleum media strategy for the cooperation council for the Arab States for the gulf-goals and mechanism', in 3rd Middle East Operational Excellence Submit Opens, National Oil and Gas Authority of Bahrain, no. 117, pp. 8.

Pyzdek, T \& Keller, P 2013, The handbook for quality management, Complete guide to operational excellence, 2nd edn, McGraw Hill, USA.

SEEP 2018, Building sector, Saudi Energy Efficiency Publication.

Solomon 2013, Fuels and refinery performance analysis, Energy Intensity Index Analysis Methodology.

Turner, CW 2001, Energy management handbook, 4th edn, The Fairmont Press, USA.

unido 2010, 'Global industrial energy efficiency benchmarking', in An Energy Policy Tool Working Paper, United Nations Industrial Development Organization, Vienna, Austria.

Worell J 2006, 'Energy efficiency improvement in the petroleum refining industry', in Advisory Committee on Energy Efficiency (ACEE) Summer Study Energy on 
Efficiency in Industry, International Electrotechnical Commission (IEC), Geneva, Switzerland.

Worland, J 2015, What to know about the historic 'Paris

agreement' on climate change, <

https://time.com/4146830/cop-21-paris-agreement-

climate/ $>$. 